\title{
Lovastatin production by an oleaginous fungus, Aspergillus terreus KPR12 using sago processing wastewater (SWW)
}

\author{
Naganandhini Srinivasan ${ }^{1}$, Kiruthika Thangavelu ${ }^{2,3}$ and Sivakumar Uthandi ${ }^{*}$ (B)
}

\begin{abstract}
Background: Lovastatin is one of the first statins to be extensively used for its cholesterol-lowering ability. It is commercially produced by fermentation. Species belonging to the genus Aspergillus are well-studied fungi that have been widely used for lovastatin production. In the present study, we produced lovastatin from sago processing wastewater (SWW) under submerged fermentation using oleaginous fungal strains, A. terreus KPR12 and A. caespitosus ASEF14.
\end{abstract}

Results: The intra- and extracellular concentrations of lovastatin produced by A. terreus KPR12 and A. caespitosus ASEF14 were lactonized. Because A. caespitosus ASEF14 produced a negligible amount of lovastatin, further kinetics of lovastatin production in SWW was studied using the KPR12 strain for 9 days. Lovastatin concentrations in the intraand extracellular fractions of the A. terreus KPR12 cultured in a synthetic medium (SM) were 117.93 and $883.28 \mathrm{mg} \mathrm{L}^{-1}$, respectively. However, these concentrations in SWW were 142.23 and $429.98 \mathrm{mg} \mathrm{L}^{-1}$, respectively. The yeast growth inhibition bioassay confirmed the antifungal property of fungal extracts. A. terreus KPR12 showed a higher inhibition zone of $14 \mathrm{~mm}$ than the ASEF14 strain. The two-way analysis of variance (ANOVA; $p<0.01$ ) showed significant differences in the localization pattern, fungal strains, growth medium, and their respective interactions. The lovastatin yield coefficient values were $0.153 \mathrm{~g} \mathrm{~g}^{-1}$ on biomass $\left(Y_{\text {LOV } / X}\right)$ and $0.043 \mathrm{~g} \mathrm{~g}^{-1}$ on the substrate, starch (Y $\mathrm{L}_{\text {Lov/S }}$ ). The pollutant level of treated SWW exhibited a reduction in total solids (TS, 59\%), total dissolved solids (TDS, 68\%), biological oxygen demand (BOD, 79.5\%), chemical oxygen demand (COD, 57.1\%), phosphate (88\%), cyanide (65.4\%), and void of nutrients such as nitrate (100\%), and ammonia (100\%).

Conclusion: The starch-rich wastewater serves as a suitable medium for A. terreus KPR12 for the production of lovastatin. It simultaneously decontaminates the sago processing wastewater, enabling its reuse for irrigation/recreation.

Keywords: Aspergillus, Lovastatin, Sago wastewater, Bioassay

*Correspondence: usivakumartnau@gmail.com

${ }^{1}$ Biocatalysts Laboratory, Department of Agricultural Microbiology, Tamil Nadu Agricultural University, Coimbatore, Tamil Nadu 641 003, India

Full list of author information is available at the end of the article permits use, sharing, adaptation, distribution and reproduction in any medium or format, as long as you give appropriate credit to the original author(s) and the source, provide a link to the Creative Commons licence, and indicate if changes were made. The images or other third party material in this article are included in the article's Creative Commons licence, unless indicated otherwise in a credit line to the material. If material is not included in the article's Creative Commons licence and your intended use is not permitted by statutory regulation or exceeds the permitted use, you will need to obtain permission directly from the copyright holder. To view a copy of this licence, visit http://creativecommons.org/licenses/by/4.0/. The Creative Commons Public Domain Dedication waiver (http://creativeco mmons.org/publicdomain/zero/1.0/) applies to the data made available in this article, unless otherwise stated in a credit line to the data. 


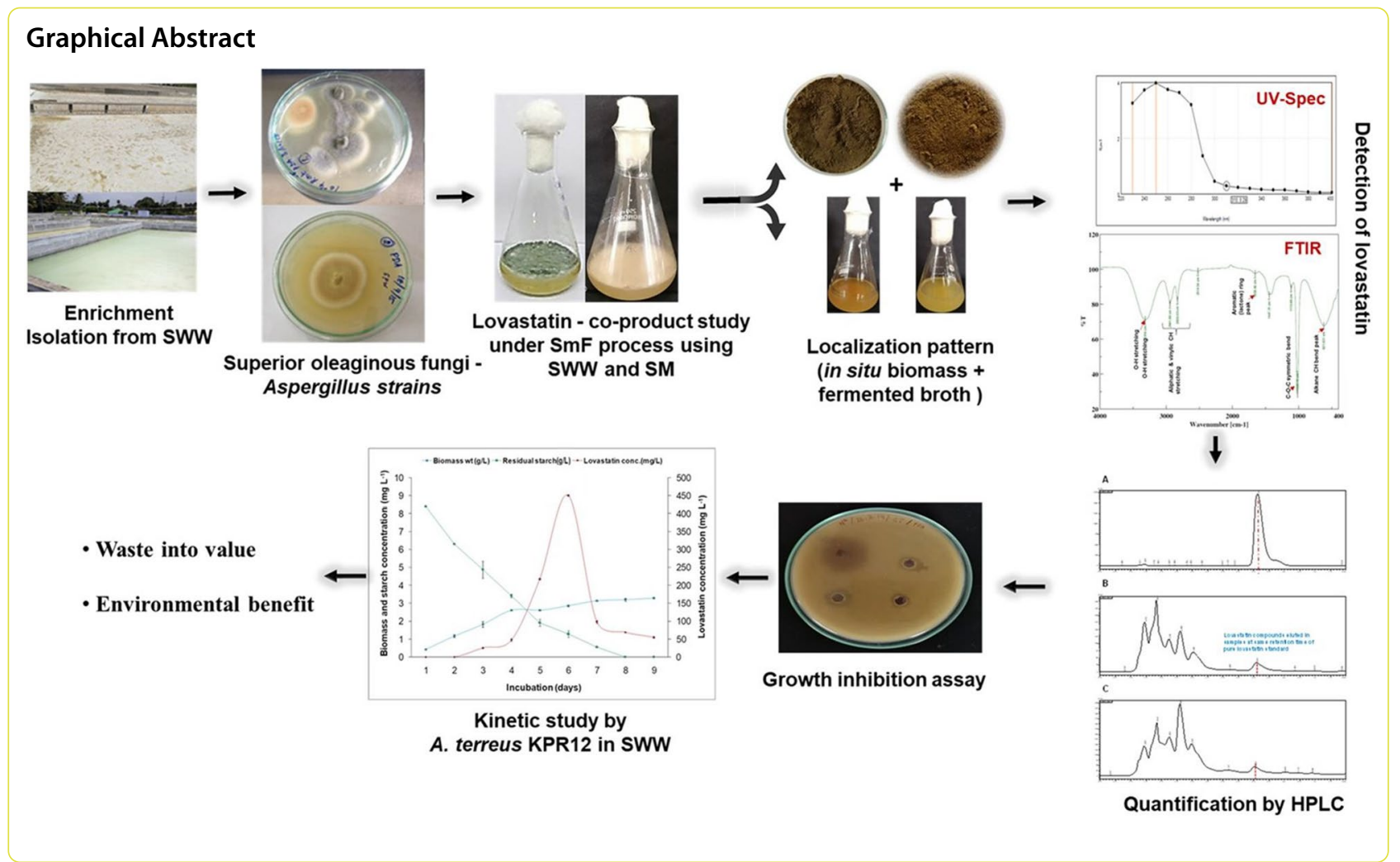

\section{Background}

Hypercholesterolemia is a well-studied metabolic disorder associated with cardiovascular morbidity and mortality in human adults [1]. Statins are widely used as cholesterol-lowering drugs that hinder the activity of the critical catalyst, 3-hydroxy-3-methylglutaryl coenzyme A (HMG-CoA) reductase (mevalonate: NADP1 enzyme EC 1.1.1.34), which is involved in the endogenous biosynthesis of LDL cholesterol $[2,3]$. Among statins, lovastatin is the first drug approved by the US Food and Drug Administration (FDA) in 1987 for the treatment of hypercholesterolemia [4]. Lovastatin has been reported to possess anticancer properties, immunomodulatory function, and anti-inflammatory activity. In addition, it is known to play a significant role in preventing neurological disorders and bone problems [5-7]. Lovastatin is a fungal secondary metabolite produced through the polyketide pathway. Several fungal genera such as Aspergillus, Penicillium, Monascus, Paecilomyces, Trichoderma, Scopulariopsis, Doratomyces, Phoma, Pythium, Gymnoascus, Hypomyces, and Pleurotus are known as lovastatin producers [8-12]. Of which, Monascus ruber and Aspergillus terreus are the foremost and targeted industrial producers of lovastatin $[4,13]$.

Lovastatin is produced using different fermentation strategies, including surface fermentation, solid-state fermentation (SSF), and submerged fermentation (SmF) $[14,15]$. For large-scale commercial production, SmF is used in batch and fed-batch modes [15]. A rich nutrient broth could be used for the production of lovastatin in the SmF process. Although several agro-wastes are used as substrates in the SSF process owing to their low cost, eco-safety, long-term availability, and easy downstream processing [16], no research has been conducted on the use of industrial wastewater.

India is one of the world's largest producers of cassava, which results in a wastewater discharge of about 40,000 to $50,000 \mathrm{~L}$ and 15 to 30 tons of sludge per unit per day to produce flour and starch $[17,18]$. Sago processing industries produce two types of wastewaters. The first type is released by the washing and peeling of cassava tubers and has low chemical oxygen demand (COD). The second type is released during the extraction of starch; it has a high pollution load due to a high COD and biological or biochemical oxygen demand (BOD); contains starch up to 7\% [19] and low concentrations of cytotoxic compounds or growth inhibitors [20]. The reported starch content of SWW was $4.82 \mathrm{~g} \mathrm{~L}^{-1}$ [21].

Applications of SWW include biogas [22, 23], hydrogen [24, 25], microbial lipid and biodiesel production using oleaginous yeast and fungi [21, 26-29]. Several oleaginous fungi and yeasts were isolated previously from this 
wastewater for biodiesel production with simultaneous removal of pollutants [27-31]. Furthermore, certain hyper oleaginous fungi such as $A$. terreus KPR12 and $A$. caespitosus ASEF14 accumulate more than $20 \%$ of their dry weight lipid [26].

We produced lovastatin with a high therapeutic value using these known lovastatin-producing fungal strains and low-cost or zero-cost waste stream sago processing wastewater (SWW) and simultaneously performed its decontamination. The produced lovastatin in SWW was characterized and quantified using ultraviolet (UV) spectrometry, Fourier transform infrared (FTIR) spectroscopy, and high-performance liquid chromatography (HPLC). The lovastatin biogenesis of $A$. terreus KPR12 in SWW was explained through a simple kinetic model.

To the best of our knowledge, this is the first report on lovastatin production using SWW. This study indicates the prospect of exploiting cheaper, large, and underutilized industrial effluent as a potential resource for the production of lovastatin in addition to the sequestration of hazardous pollutants present in SWW.

\section{Materials and methods}

\section{Fungal strains and culture conditions}

A. caespitosus ASEF14 and A. terreus KPR12 were isolated, identified, characterized, and screened for oleaginicity, amylase secretion, and cyanide degradation in SWW $[27,28,30]$. In addition to biolipid production, these two fungal strains were screened for the production of co-metabolite, lovastatin in synthetic medium (SM), as well as SWW [26]. The GenBank accession numbers of these strains are MF599090 and MF599091. The cultures were maintained on potato dextrose agar (PDA) slants at $4{ }^{\circ} \mathrm{C}$.

\section{Physicochemical characterization of SWW}

The collection and characterization of SWW used in the present work have been reported in our previous work [28]. The initial starch concentration of SWW was adjusted to $10 \mathrm{~g} \mathrm{~L}^{-1}$, and other physicochemical parameters included $\mathrm{pH}$ 4.6, electrical conductivity (EC) $6.3 \mathrm{dS} \mathrm{m}^{-1}$, salinity $4.86 \mathrm{~g} \mathrm{~L}^{-1}$, total solids (TS) $4.57 \mathrm{~g} \mathrm{~L} \mathrm{~L}^{-1}$, total dissolved solids (TDS) $4.16 \mathrm{~g} \mathrm{~L}^{-1}$, nitrate $3.10 \mathrm{mg} \mathrm{L}^{-1}$, ammonia $5.48 \mathrm{mg} \mathrm{L}^{-1}$, phosphate $611.67 \mathrm{mg} \mathrm{L}^{-1}$, biological oxygen demand (BOD) $5.04 \mathrm{~g} \mathrm{~L}^{-1}$, chemical oxygen demand (COD) $70.67 \mathrm{~g} \mathrm{~L}^{-1}$, and cyanide $4.46 \mathrm{mg} \mathrm{L}^{-1}$.

\section{Preparation of seed inoculant}

The fungal strains of $A$. terreus KPR12 and A. caespitosus ASEF14 were grown on PDA incubated at $30{ }^{\circ} \mathrm{C}$ for 5 days, and stored under refrigeration at $4{ }^{\circ} \mathrm{C}$. The conidiospores from the above strains were harvested separately with sterile solution $(0.05 \%$ Tween 80 and $0.9 \% \mathrm{NaCl})$, washed twice with $0.1 \mathrm{M}$ sterile phosphate buffer $(\mathrm{pH}$ 6), and adjusted to contain $10^{7}$ spores $\mathrm{mL}^{-1}$. An aliquot of a spore suspension of each culture $(1 \mathrm{~mL})$ was inoculated into $50 \mathrm{~mL}$ of potato dextrose broth $(\mathrm{pH}$ 6.5) in a $250 \mathrm{~mL}$ Erlenmeyer flask and incubated at $30^{\circ} \mathrm{C}$ under a static condition for $72 \mathrm{~h}$ until the exponential growth was reached.

\section{Fermentation conditions and lovastatin production}

The two fungal strains grown under $\mathrm{SmF}$ conditions in SM and SWW were tested for lovastatin production. About $100 \mathrm{~mL}$ of sterile SM and SWW were taken in a $250 \mathrm{~mL}$ Erlenmeyer flask, and $10 \%$ of prepared liquid seed inoculum of $A$. caespitosus ASEF14 and A. terreus KPR12 was inoculated separately to the production media in the flasks. Before inoculation, the $\mathrm{pH}$ of both liquid substrates was adjusted to 6.5 using $0.1 \mathrm{~N} \mathrm{HCl}$ or $0.1 \mathrm{~N} \mathrm{NaOH}$. The initial starch content of SWW was $4.82 \mathrm{~g} \mathrm{~L}^{-1}$ and adjusted to $10 \mathrm{~g} \mathrm{~L}^{-1}$. The flasks were incubated at $30^{\circ} \mathrm{C}$ for 6 days under non-shaking conditions. The composition of the SM media (per $\mathrm{L}$ ) was as follows: $10 \mathrm{~g}$ starch, $0.5 \mathrm{~g}$ ammonium sulfate, $7 \mathrm{~g}$ potassium dihydrogen phosphate, $2.5 \mathrm{~g}$ disodium hydrogen phosphate, $1.5 \mathrm{~g}$ magnesium sulfate, $0.15 \mathrm{~g}$ ferric chloride, $0.15 \mathrm{~g}$ calcium chloride, $0.02 \mathrm{~g}$ zinc sulfate, and $0.06 \mathrm{~g}$ manganese sulfate.

\section{Biomass estimation}

After fermentation, fungal mats in SM and SWW were separated by filtration through pre-weighed Whatman grade 1 filter paper. The biomass obtained by filtration was washed twice with distilled water and subjected to drying at $50^{\circ} \mathrm{C}$ until it reached a constant weight. The dry weight of biomass was calculated by gravimetric analysis [12].

\section{Extraction of intracellular lovastatin}

To measure the intracellular concentrations of statin, the dry mycelium $(0.5 \mathrm{~g})$ was ruptured by ultrasonication for 5 min (PCI Analytics; Mumbai, India). The sonicated samples were adjusted to $\mathrm{pH} 3.0$ using $2 \mathrm{NH}_{3} \mathrm{PO}_{4}$ and extracted with $10 \mathrm{~mL}$ of ethyl acetate in a shaker incubator at $180 \mathrm{rpm}$ at $30^{\circ} \mathrm{C}$ for $2 \mathrm{~h}$. The organic and aqueous phases of the filtrates were separated by cold centrifugation $\left(4{ }^{\circ} \mathrm{C}\right)$ at $6000 \mathrm{rpm}$ for $10 \mathrm{~min}$. The organic phases were collected, lactonized with $1 \%$ trifluoroacetic acid, and concentrated under reduced pressure. The dried residue was dissolved in $1 \mathrm{~mL}$ acetonitrile, filtered through a $0.45 \mu \mathrm{m}$ filter, collected in clean brown glass vials, and stored at $4{ }^{\circ} \mathrm{C}$ for ultraviolet (UV) spectrophotometry, Fourier transform infrared (FTIR) spectroscopy, and 
high-performance liquid chromatography (HPLC) analysis [32].

\section{Extraction of extracellular lovastatin}

To measure the extracellular concentrations of lovastatin, the fermentation broths of SM and SWW were acidified to $\mathrm{pH} 3.0$ by the addition of $10 \% 1 \mathrm{~N} \mathrm{HCl}$. The acidified broths were extracted with an equal volume of ethyl acetate under shaking conditions $(180 \mathrm{rpm})$ at $30^{\circ} \mathrm{C}$ for $2 \mathrm{~h}$. The organic and aqueous phases of filtrates were separated by cold centrifugation $\left(4{ }^{\circ} \mathrm{C}\right)$ at $6000 \mathrm{rpm}$ for $10 \mathrm{~min}$. The organic phases were collected, lactonized, concentrated, and analyzed as intracellular lovastatin [32].

\section{Analytical methods UV spectrophotometric method}

The filtered fungal extracts were analyzed qualitatively for the presence of lovastatin using UV-visible spectrophotometer (SpectraMax i3x, Sunnyvale, California, US) [33]. The radiation source was a deuterium lamp emitting a continuous UV spectrum between 210 and $360 \mathrm{~nm}$. The lovastatin spectrum was recorded in the absorbance mode at $247 \mathrm{~nm}$ and $258 \mathrm{~nm}$, respectively. Pure lovastatin (Sigma Aldrich, St. Louis, Missouri, US) was used as a standard for comparison.

\section{Fourier transform-infrared spectroscopy}

FTIR measurements of the samples were performed using attenuated total reflectance (ATR) equipped with a deuterated triglycine sulfate (DTGS) detector (JASCO FT/IR-6300, Japan). The crude sample $(10 \mu \mathrm{L})$ was directly placed on the surface of the diamond crystal. Samples were scanned using absorbance spectra at wavenumbers 400 to $4000 \mathrm{~cm}^{-1}$ at a resolution of $1 \mathrm{~cm}^{-1}$ for each interferogram.

\section{High-performance liquid chromatography}

The sample extracts were quantitatively analyzed for the presence of lovastatin using HPLC device, Shimadzu Nexera X2 (Shimadzu, Prominence HPLC, Kyoto, Japan) with a UV detector and a C18 column. Acetonitrile and water (acidified with $1.1 \%$ phosphoric acid) in the ratio of 70:30 v/v were used as mobile phase. The eluent flow rate and the column temperature were maintained at $1 \mathrm{~mL} \mathrm{~min}{ }^{-1}$ and $40{ }^{\circ} \mathrm{C}$, respectively. The detection was performed at $238 \mathrm{~nm}$ wavelengths, with an injection volume of $20 \mu \mathrm{L}$. Lovastatin standard was prepared according to the manufacturer's instructions [34]. Lovastatin was identified in the sample by comparing the retention times with the standards.

\section{Kinetics of lovastatin production in SWW by A. terreus KPR12}

A $250 \mathrm{~mL}$ Erlenmeyer flask containing approximately $100 \mathrm{~mL}$ of SWW was sterilized, inoculated with $10 \%$ of A. terreus KPR 12 inoculum, and incubated at $30{ }^{\circ} \mathrm{C}$. The culture broth was harvested from day 1 until day 9 to monitor the growth of strains and production of lovastatin. The cell dry weight was determined by gravimetric analysis. The amount of lovastatin was determined using HPLC as mentioned in the analytical methods section. Residual starch in SWW was analyzed using the phenol sulfuric acid method [35]. The following kinetic and stoichiometric parameters used to describe the growth of strains and production of lovastatin by $A$. terreus KPR12 was determined.

The substrate consumption rate $(r)$ is expressed in days.

$$
r=\left(S_{i}-S_{o}\right) / \Delta \mathrm{t},
$$

where $S_{i}$ is the initial concentration and $S_{o}$ is the final concentration of substrate (s).

The lovastatin yield coefficient $(\mathrm{Y})$ was determined relative to the production of biomass $(\mathrm{X})$ or the consumption of total substrate $(\mathrm{S})$ in the reaction.

$$
\begin{aligned}
& \mathrm{Y}_{\mathrm{LOV} / \mathrm{X}}=\left(P_{\max }-P_{i}\right) /\left(X_{\max }-X_{i}\right) \\
& \mathrm{Y}_{\mathrm{LOV} / \mathrm{S}}=\left(P_{\max }-P_{i}\right) /\left(S_{i}-S_{o}\right)
\end{aligned}
$$

$\mathrm{P}_{\max }$ is the maximum concentration of lovastatin, and $\mathrm{P}_{\mathrm{i}}$ is the initial concentration of lovastatin in the above equation. $\mu_{\max }$ is the maximum specific growth rate obtained from a plot of the specific biomass concentration versus time.

\section{Bioassay}

The yeast growth inhibition bioassay was performed using the agar well diffusion method [36]. Candida tropicalis ASY2 (Acc no. MH011502) was used as a test organism. Cells of the C. tropicalis ASY2 were suspended in phosphate-buffered saline and spread onto the yeast extract peptone dextrose (YEPD) medium. Wells were made using a sterile cork borer of $6 \mathrm{~mm}$ diameter. Further, $100 \mu \mathrm{L}$ of intra- and extracellular extract of the fungus KPR12 was loaded into separate wells. Ethyl acetate and the standard solution of lovastatin $(10 \mathrm{mg}$ dissolved in $100 \mathrm{~mL}$ of ethyl acetate) (Sigma Aldrich) were used as negative and positive controls, respectively. The standard was prepared according to the method of Friedrich et al. [37] with a slight modification, in which the lovastatin was suspended in ethyl acetate followed by sonication and filtration. All plates were incubated at $30{ }^{\circ} \mathrm{C}$ for 16 to $24 \mathrm{~h}$. A clear inhibition zone around the indicator 
organisms was observed, and the diameter of the inhibition zone is proportional to the concentration of lovastatin in samples.

\section{Characterization of decontaminated SWW}

The nutrient and toxicant removal efficiency of $A$. terreus KPR12 in the SWW was studied along with lovastatin kinetics. After fermentation, the spent SWW was filtered, and the physicochemical parameters were determined according to the standard method of water and wastewater analysis [38]. The cyanide content in SWW was estimated using the modified picric acid method [39].

\section{Statistical analysis}

Data were subjected to statistical analysis using the Microsoft Excel for Windows 2007 add-ins with XLSTAT version 2010.5.05 [40], and all experiments were performed in triplicate. Statistically significant differences between the means of groups and their interactions were determined using one-way and two-way analysis of variance (ANOVA) and Duncan's multiple range test (DMRT) at the $5 \%$ significance level.

\section{Geolocation information}

The Tamil Nadu Agricultural University's global positioning system (GPS) coordinates are latitude: $11^{\circ} 07^{\prime} 3.36^{\prime \prime} \mathrm{N}$ and longitude: $76^{\circ} 59^{\prime} 39.91^{\prime \prime} \mathrm{E}$.

\section{Results and discussion}

In the present study, we produced cholesterol-reducing lovastatin using SWW under SmF using oleaginous fungal strains $A$. caespitosus ASEF14 and $A$. terreus KPR12. Initially, the fermentation was performed for 6 days. After the extraction of lovastatin from the broth of SM and SWW (extracellular) and fungal mycelium (intracellular), it was acidified and lactonized with $1 \%$ trifluoroacetic acid. This process can transform the acid form of lovastatin into the lactone form.

Generally, lovastatin exists in both open-ring $\beta$-hydroxy acid (active) and closed-ring $\beta$-lactone forms (inactive) (Fig. 1). The physicochemical and pharmaceutical properties of these two forms are different and interchangeable $[6,41]$. In the broth culture media, the filamentous fungi secrete lovastatin mostly in its hydroxy acid form. However, the lactone form of industrial lovastatin makes it a viable option for subsequent quantification analyses. Therefore, the reduction in $\mathrm{pH}$ and lactonization converts the acid form to lactone for the quantification of lovastatin $[13,41]$. In the present investigation, the adopted techniques ensured the accurate quantification of lovastatin in fermentation broth samples.

\section{Analysis of lovastatin in fungal crude extracts}

The lactonized lovastatin extracts from the samples were qualitatively analyzed using the UV-visible spectrophotometer and compared to the lovastatin absorption spectrum (Fig. 2A). The lovastatin compound had a UV-absorbing peak at $247 \mathrm{~nm}$ (Fig. 2A). Such an absorption band corresponds to the $\pi-\pi$ transition due to the conjugated double bonds. As seen in Fig. 2A, intra- and extracellular fractions of $A$. terreus KPR12 from SM and SWW had the same UV absorption spectra as the lovastatin standard $\left(\lambda_{\max }=247,258 \mathrm{~nm}\right)$. The UV absorption spectra of intra- and extracellular fractions of $A$. caespitosus ASEF14 (Fig. 2B) revealed that the intracellular fraction exhibited an absorption spectrum similar to that of the lovastatin standard. In contrast, the extracellular fraction of SM and SWW revealed a distinct pattern, such as stationary phase lines indicated the presence of non-lovastatin compounds. It has been reported three different maximum absorptions at 232, 238, and $247 \mathrm{~nm}$ of pure lovastatin, suggesting its better identification from other

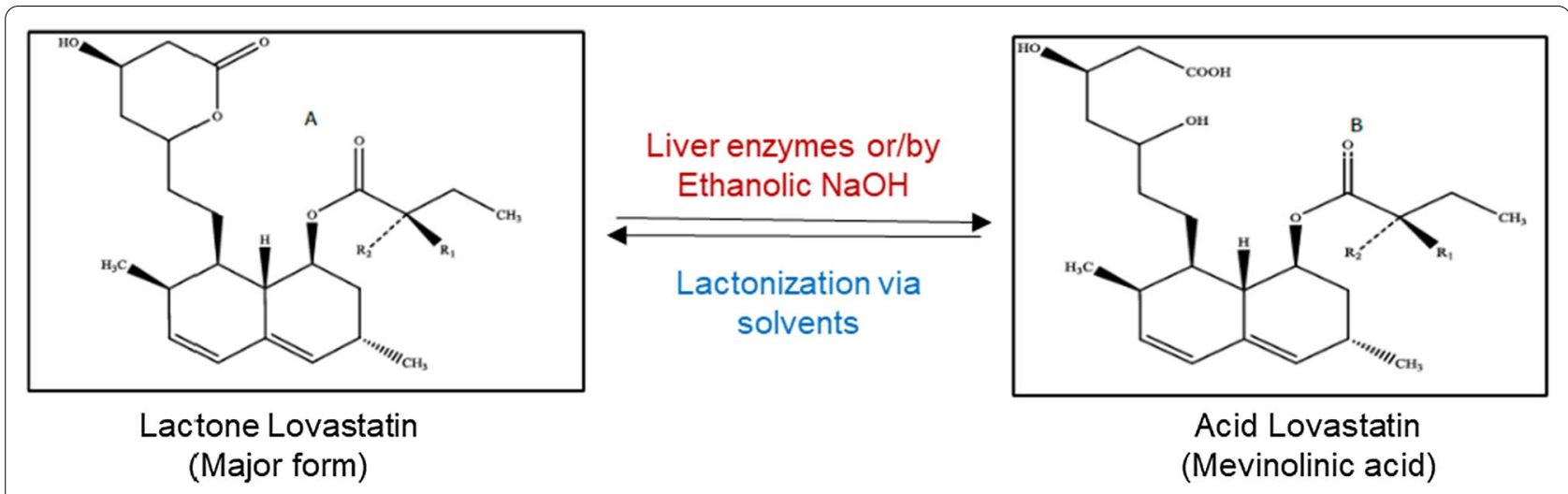

Fig. 1 Closed-ring lactone (inactive) and open-ring hydroxy form (active) of lovastatin produced by filamentous fungi 

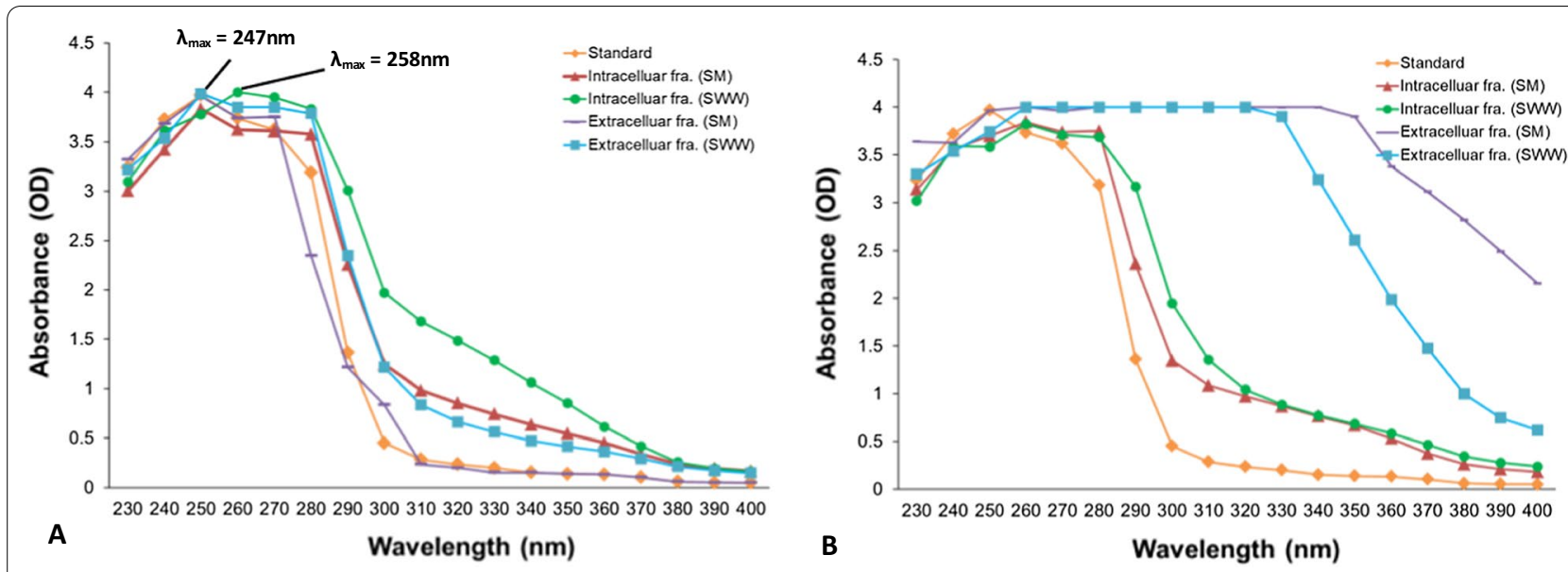

Fig. 2 UV spectrophotometric analysis of intra- and extracellular fractions of A. terreus KPR12 (A) and A. caespitosus ASEF14 (B) grown in SM and SWW under SmF

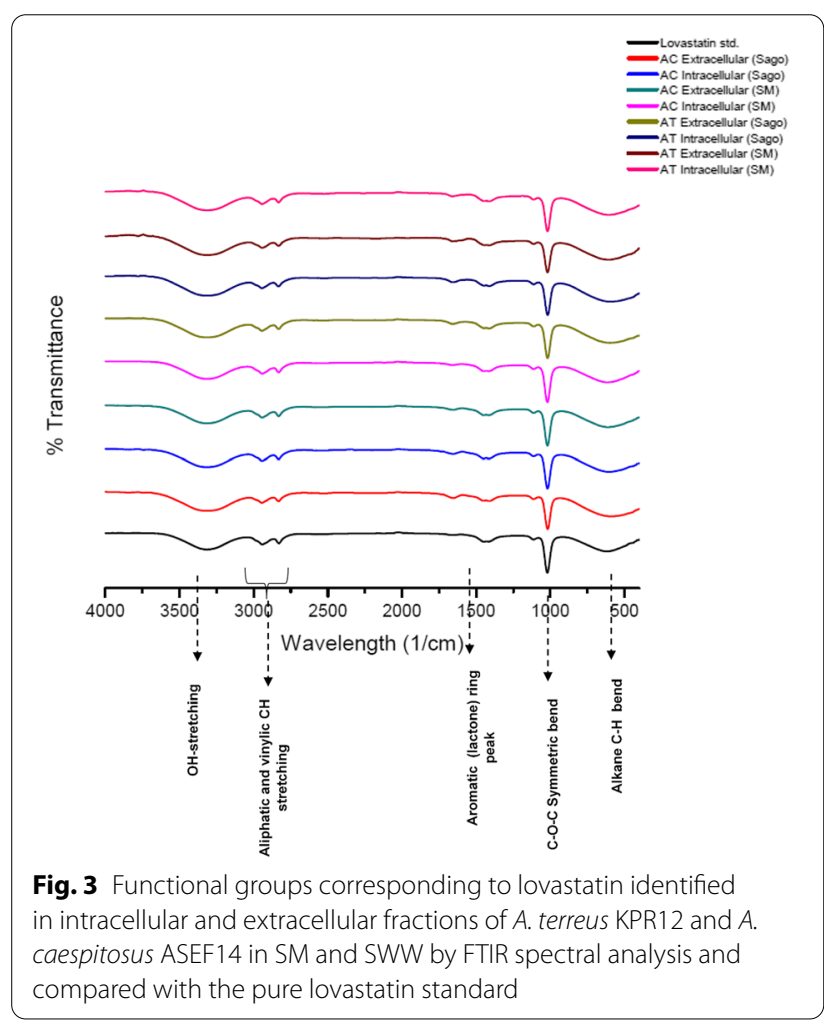

compounds, which is due to the presence of dienes [6, 42]. The spectrophotometric analysis of lovastatin is easy, quick, eco-friendly, and less laborious than other analytical techniques. Based on these observations, the UV absorption spectrum of A. terreus KPR12 confirmed the synthesis of lovastatin.

\section{FTIR spectral analysis of lovastatin}

The FTIR spectra of fungal extracts were analyzed by interferometry using the pure lovastatin standard (Fig. 3). All spectra were recorded in the range of 400 to $4000 \mathrm{~cm}^{-1}$. A narrow band at 3400 to $3500 \mathrm{~cm}^{-1}$ indicated the presence of non-hydrogen bonded $\mathrm{O}-\mathrm{H}$ stretches. Vibration often occurs to the left of this peak, suggesting the alcoholic/phenolic hydroxyl groups. The olefinic $\mathrm{C}-\mathrm{H}$ stretching vibration band observed at $2941.88 \mathrm{~cm}^{-1}$ is a particular characteristic of chitin, a crucial component of the cell wall, and ergosterol [43]. The peaks between 2900 and $3000 \mathrm{~cm}^{-1}$ are aliphatic and vinylic $\mathrm{C}-\mathrm{H}$ stretching. Similarly, a band at $1447.31 \mathrm{~cm}^{-1}$ represented two carbonyl ester groups for bending vibrations in methyl and methylene groups. The symmetric bending of the $\mathrm{C}-\mathrm{O}-\mathrm{C}$ ester and alkane $\mathrm{C}-\mathrm{H}$ bonds at $1020.16 \mathrm{~cm}^{-1}$ and between 680 and $610 \mathrm{~cm}^{-1}$, respectively, corresponds to specific functional peaks of lovastatin (Fig. 3). The $\mathrm{C}-\mathrm{H}$ stretching absorptions were observed below $3000 \mathrm{~cm}^{-1}$. Certain band structures observed between 3150 and $3000 \mathrm{~cm}^{-1}$ represents unsaturation $(\mathrm{C}=\mathrm{C}-\mathrm{H})$ and aromatic rings. The other most important bands were aromatic ring vibrations at around 1500 to $1600 \mathrm{~cm}^{-1}$, which usually appeared as a pair of band structures in the lovastatin [44]. These FTIR spectra confirmed the presence of lovastatin in the fungal extracts and fractions (Fig. 3).

\section{Quantification of lovastatin}

Lovastatin produced by two different fungal strains grown in SM and SWW was quantified using HPLC. The retention time (5.124) of the first peak for both fungal extracts was similar to the standard lovastatin, and the 


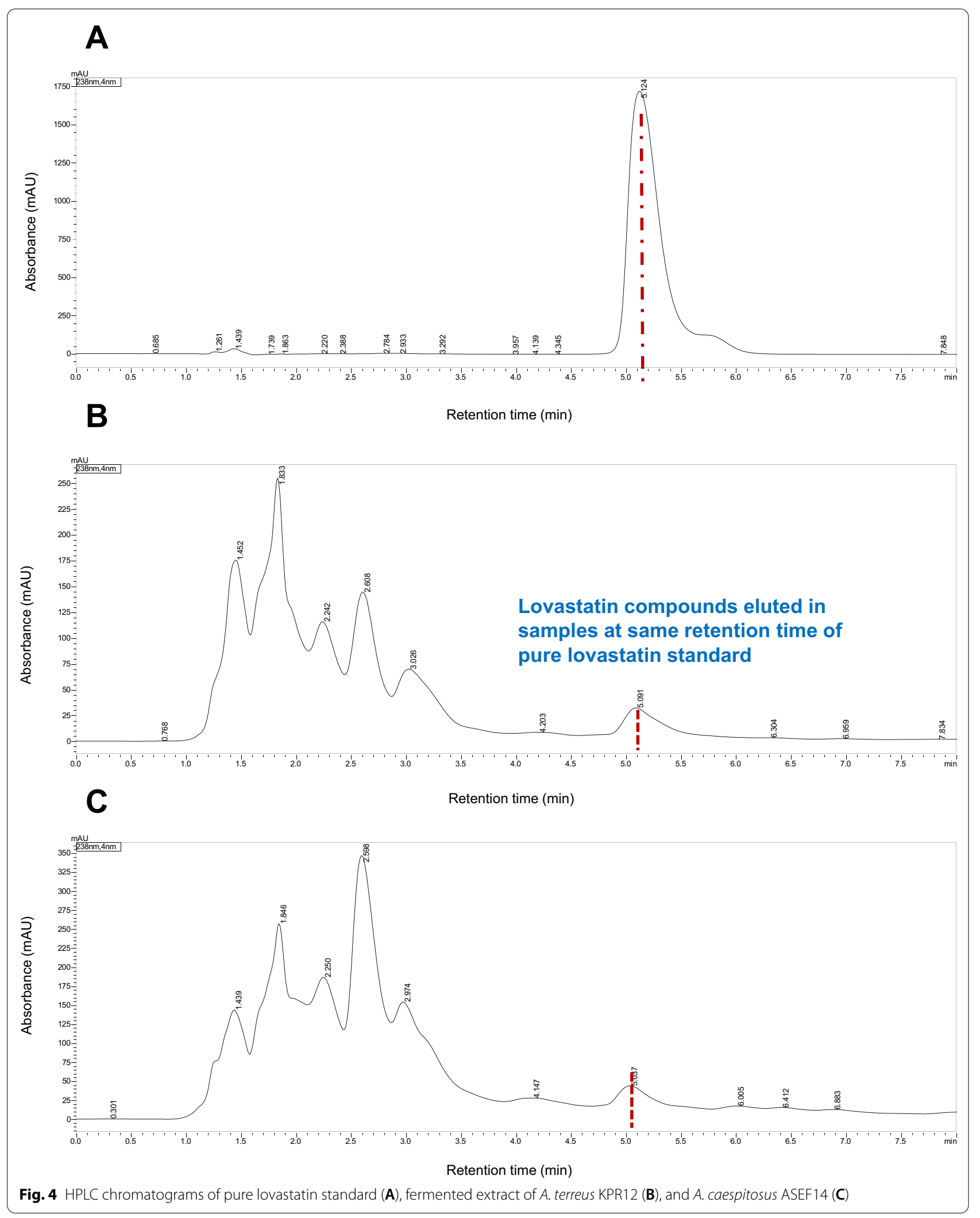


appearance of other peaks in the samples might be due to the presence of impurities or unidentified compounds produced during the fermentation process (Fig. 4A-C). The concentrations of lovastatin in the intra- and extracellular fractions of KPR12 grown in the SM were 117.93 and $883.28 \mathrm{mg} \mathrm{L}^{-1}$, respectively; however, in SWW, lovastatin yield were 142.23 and $429.98 \mathrm{mg} \mathrm{L}^{-1}$, respectively (Fig. 5A). Moreover, the lovastatin concentrations in intra- and extracellular fractions of ASEF14 grown in SM were 7.64 and $2.94 \mathrm{mg} \mathrm{L}^{-1}$, and in SWW, these were 13.57 and $0.62 \mathrm{mg} \mathrm{L}^{-1}$, respectively (Fig. $5 \mathrm{~B}$ ). The results demonstrated that the fungal strain KPR12 was superior to ASEF14 in terms of intra- and extracellular fractions, irrespective of SM and SWW. Therefore, a further experimental study focused only on the high lovastatin-yielding fungus KPR12.

The media conditions and compositions exert varying effects on the production of fungal secondary metabolites [45]. The synthesis of such secondary metabolites occurs at the end of the logarithmic (log) growth phase, in which the essential nutrients are in low supply. The secretion of accumulated metabolites into the surrounding medium is necessary. Fungal strains grown on a synthetic starchbased substrate medium can secrete a high amount of
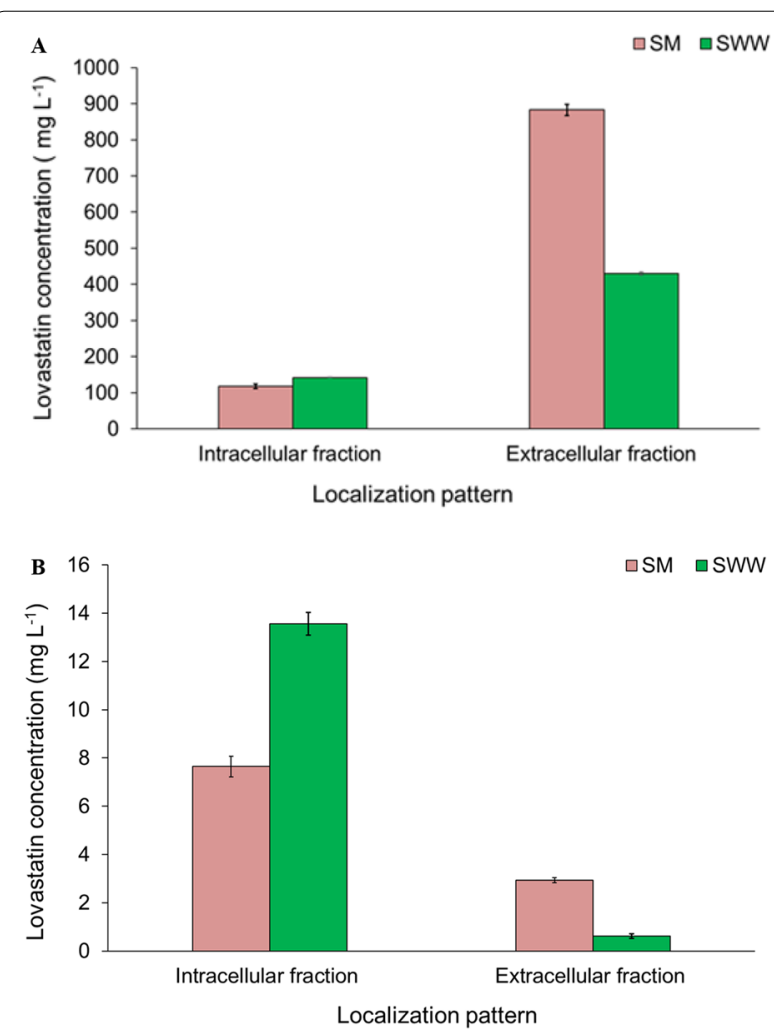

Fig. 5 Lovastatin content in intracellular and extracellular fractions of A. terreus KPR12 (A) and A. caespitosus ASEF14 (B) grown in SM and SWW lovastatin as an extracellular fraction. In this study, a 2.04 fold increase and 1.2 fold decrease was observed in extracellular and intracellular concentrations of lovastatin by KPR12 in the SM compared to SWW, respectively. This lower secretion could be attributed to the mass transfer resistance limits in SWW [46]. In addition, SWW contains hydrogen cyanide ( $\mathrm{HCN})$, which is generated during milling processes such as peeling, slicing, squeezing, and crushing cassava tubers. At high concentrations, cyanide becomes toxic to living organisms. Apart from its toxic nature, cyanide is well-known for its metabolic inhibitory effects $[47,48]$. This may also affect the extracellular secretion by fungi. Ultimately, the extraction of lovastatin from the intracellular portion of fungal cultures complicates the downstream processing due to the presence of structural analogs and intermediates [49]. The production of lovastatin is highly influenced by slowly metabolized carbon sources (lactose, glycerol, and fructose) compared to glucose $[8,50]$. The pathway leading to lovastatin synthesis using carbon is slower than the one that uses carbon for biomass production (glucose) because lovastatin is a product of secondary metabolism. Thus, starch, a slowly metabolized carbon source present in SWW and SM, could affect the production of biomass and lovastatin.

Although the lovastatin content was lower in SWW than in SM; it was selected for kinetic analysis owing to its low-cost nature, high availability, economic factors, and environmental impact. All data were analyzed using a two-way ANOVA, and the results indicated significant differences $(p<0.05)$ in the localization pattern, fungal strains, growth media, and their interactions (Table 1).

\section{Kinetics of lovastatin production by $A$. terreus KPR12 in SWW}

The fermentation cycle was conducted for 9 days. The lovastatin content, dry cell weight, residual starch, and other physicochemical changes were measured periodically in SWW (Fig. 6). The results revealed that lovastatin was not detected in the first 2 days of fermentation. Lovastatin, a product of secondary metabolism, is produced at the end of the log or during stationary growth phase of fungi. It cannot secrete or synthesize at the early growth stage of fungi [15]. The secretion of lovastatin in SWW started on the third day of fermentation using $5.13 \mathrm{~g} \mathrm{~L}^{-1}$ starch and produced biomass of $1.82 \mathrm{~g} \mathrm{~L}^{-1}$. The maximum extracellular concentration of lovastatin was $451 \mathrm{mg} \mathrm{L}^{-1}$ with a dry weight of $2.86 \mathrm{~g} \mathrm{~L}^{-1}$ on the 6th day of fermentation.

The lovastatin synthesis pathway consumes carbon more slowly than the biomass growth process. The synthesis of building blocks for biomass synthesis is hindered by nitrogen limitation, and the extra carbon is 
Table 1 Statistical parameters of two-factor ANOVA of lovastatin production as affected by cultivation medium, strains, and localization

\begin{tabular}{|c|c|c|c|c|c|c|}
\hline Effect & SS & DF & MS & $F$ & Prob F & Sign \\
\hline Growth medium & $45,240.80$ & 1 & $45,240.80$ & 607.68 & $7.8354 \times 10^{-9}$ & $* *$ \\
\hline Strains & $599,563.59$ & 1 & $599,563.59$ & 8053.44 & $2.65301 \times 10^{-13}$ & ** \\
\hline Fraction & $268,032.72$ & 1 & $268,032.72$ & 3600.26 & $6.61319 \times 10^{-12}$ & $* *$ \\
\hline Growth medium $\times$ strains & $46,782.23$ & 1 & $46,782.23$ & 628.39 & $6.86322 \times 10^{-9}$ & $* *$ \\
\hline Growth medium $\times$ fraction & $59,010.85$ & 1 & $59,010.85$ & 792.64 & $2.73655 \times 10^{-9}$ & $* *$ \\
\hline Strains $\times$ fraction & $286,637.61$ & 1 & $286,637.61$ & 3850.17 & $5.05888 \times 10^{-12}$ & ** \\
\hline Growth medium $\times$ strains $\times$ fraction & $55,069.78$ & 1 & $55,069.78$ & 739.71 & $3.59881 \times 10^{-9}$ & ** \\
\hline Residual & 595.58 & 8 & 74.45 & & & \\
\hline Total & $1,360,933.16$ & 15 & $90,728.88$ & & & \\
\hline CV (\%) & 4.32 & & & & & \\
\hline
\end{tabular}

Growth medium - SM and SWW; Strains-A. terreus KPR12 and A. caespitosus ASEF14; Fraction-Intracellular and extracellular fraction; SS—-sum of the squares; DFdegrees of freedom; MS—Mean sum of the squares; F-F test; Prob F-F probability; Sign.—significant at ${ }^{*} p<0.05 ;{ }^{* *} p<0.01$

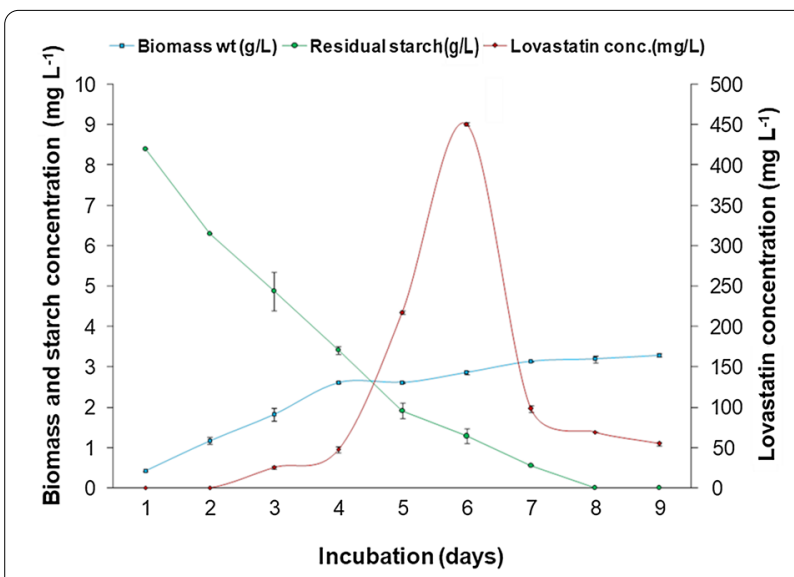

Fig. 6 Growth kinetics and lovastatin production by A. terreus KPR12 in SWW

channeled into lovastatin production. Polyketide synthase (PKS: non-aketide synthase [LNKS]+diketide synthase [LDKS]), a multifunctional enzyme complex, is involved in the biosynthesis of lovastatin [51]. This enzyme followed the hyperbolic relationship when the substrate concentration was low. In the current investigation, a steep increase in the rate of reaction (lovastatin synthesis) with the availability of substrate was observed, i.e., starch (Fig. 6). When starch is unavailable, the enzyme catalytic site becomes vacant [52]. Thus, the rate at which lovastatin synthesis drops dramatically (Fig. 6).

The results showed that the lovastatin yield would be enhanced if essential nutrients were present in the medium. Such findings were consistent with Hajjaj et al. [53] and observed that the relatively low levels of lovastatin produced $\left(0.034 \mathrm{mg} \mathrm{g}^{-1} \mathrm{~h}^{-1}\right)$ in cultures growing at a high specific growth rate $\left(0.070 \mathrm{~h}^{-1}\right)$, whereas
Table 2 Kinetic parameters of lovastatin production by A. terreus KPR12 grown in SWW

\begin{tabular}{ll}
\hline Kinetic parameters & Values \\
\hline Lovastatin to biomass yield coefficient $\left(Y_{\text {LoV/X }}\right)$ & $0.153 \mathrm{~g} \mathrm{~g}^{-1}$ \\
Lovastatin to starch yield coefficient $\left(Y_{\text {Lov/S }}\right)$ & $0.043 \mathrm{~g} \mathrm{~g}^{-1}$ \\
Maximum specific formation rate of lovastatin $\left(Q_{\text {max }}\right)$ & $0.0011 \mathrm{~g} \mathrm{~g}^{-1} \mathrm{~h}^{-1}$ \\
Biomass to starch yield coefficient $\left(Y_{X / S}\right)$ & $0.278 \mathrm{~g} \mathrm{~g}^{-1}$ \\
Final biomass weight $\left(X_{\text {Final }}\right)$ & $3.20 \mathrm{~g} \mathrm{~L}^{-1}$ \\
\hline
\end{tabular}

higher productivity $\left(0.093 \mathrm{mg} \mathrm{g}^{-1} \mathrm{~h}^{-1}\right)$ was achieved at lower growth rates $\left(0.052 \mathrm{~h}^{-1}\right)$. Starvation due to a lack of essential nutrients (no residual starch content in SWW) in this study appeared to block fungal growth and lovastatin production.

The kinetic parameters of $A$. terreus KPR12 grown in SWW are shown in Table 2. The adjusted initial starch content used for this kinetic study was $10 \mathrm{~g} \mathrm{~L}^{-1}$. The final biomass $\left(\mathrm{X}_{\mathrm{FINAL}}\right)$ (on a dry weight basis) obtained by the fungi in SWW was $3.20 \mathrm{~g} \mathrm{~L}^{-1}$. The lovastatin yield coefficients on biomass $\left(\mathrm{Y}_{\mathrm{LOV} / \mathrm{X}}\right)$ and on the substrate $\left(\mathrm{Y}_{\mathrm{LOV} / \mathrm{S}}\right)$ were found to be 0.153 and $0.043 \mathrm{~g} \mathrm{~g}^{-1}$, respectively. Bizukojc and Ledakowicz [54] documented lovastatin yield coefficients of 0.0065 and $0.0050 \mathrm{~g} \mathrm{~g}^{-1}$ by $A$. terreus using lactose and glycerol in the culture, respectively. Lovastatin to biomass yield coefficient was 0.0052 , and the initial lactose and glycerol contents were 10 and $5 \mathrm{~g} \mathrm{~L}^{-1}$, respectively. The results showed that a higher yield of lovastatin was obtained using pure sugar.

In the current study, the biomass to starch yield coefficient and the maximum specific lovastatin formation rates $\left(\mathrm{Q}_{\max }\right)$ in SWW were $0.278 \mathrm{~g} \mathrm{~g}^{-1}$ and $0.0011 \mathrm{~g} \mathrm{~g}^{-1} \mathrm{~h}^{-1}$, respectively. Pawlak and Bizukojć [55] 
reported that biomass to lactose and biomass to glycerol yield coefficients by $A$. terreus were $0.55 \mathrm{~g}$ biomass/g lactose and $0.55 \mathrm{~g}$ biomass/g glycerol in fed-batch fermentation with an initial lactose and glycerol concentrations of 10 and $5 \mathrm{~g} \mathrm{~L}^{-1}$, respectively. The maximum specific lovastatin formation rate $\left(\mathrm{Q}_{\max }\right)$ was $0.00178 \mathrm{~g} \mathrm{~g}^{-1} \mathrm{~h}^{-1}$. Based on the kinetic results obtained in the present study, SWW can be used as the growth substrate for the effective production of various biomolecules. Moreover, the synthesis of secondary molecules depends on strains and culture conditions.

The lovastatin yield of $A$. terreus KPR12 under submerged fermentation in SWW was compared with other studies using diverse carbon sources (Table 3). In a study, Jaivel and Marimuthu [56] demonstrated that glucose was used as a sole carbon source to evaluate the ability of 10 fungal strains from various natural sources for the production of lovastatin and identified A. terreus (JPM3) as a better producer of lovastatin with a yield of $138.4 \mathrm{mg} \mathrm{L}^{-1}$. In our study, the fungal strain A. terreus KPR 12 produced nearly 3.3 fold higher yield than the previous report [56]. Jia et al. [57] used soluble starch as a source of carbon and reported a 0.8 fold increase in the yield compared to the present study. Pecyna and Bizukojc [58] analyzed specific lovastatin yield during SmF using the lactose-to-glycerol ratio and found a lovastatin yield of $161.8 \mathrm{mg} \mathrm{L}^{-1}$. However, the current study indicates a 2.7 fold higher lovastatin output than the above studies. Sridevi and Charya [59] isolated various strains of $A$. terreus from soil samples and screened for the production of lovastatin using the agar plug assay method, and the maximum production of lovastatin $\left(360 \mathrm{mg} \mathrm{L}^{-1}\right.$ ) was obtained using $A$. terreus KSVL-SUCP-75. When compared to this value (360 $\mathrm{mg} \mathrm{L}^{-1}$ ), the yield obtained from our research was 1.25 fold higher. In other studies, strain improvement techniques were adopted $[60,61]$ or supplements were added to the culture medium [31, 62] to increase the lovastatin titer. The results of the present study demonstrated that $A$. terreus KPR12 can be a potential lovastatin-producing strain, which effectively utilizes a waste stream to produce therapeutic metabolites.

\section{Yeast growth inhibition bioassay}

Aspergillus species have proven to be a prolific source of secondary metabolites with interesting biological activities, including antibacterial activity $[63,64]$. Lovastatin is known for its antifungal activity; it inhibits the growth of several fungal genera, including Saccharomyces cerevisiae, Candida spp., Aspergillus spp., and Cryptococcus spp., by inhibiting HMG-CoA reductase that depletes ergosterol, the fungal counterpart of cholesterol [65-67]. Both ergosterol and cholesterol are important for cell viability and membrane fluidity, and they follow a similar mechanism. The ethyl acetate extract of Aspergillus contains several antimicrobial compounds such as helvolic acid, monomethylsulochrin, ergosterol, terreic acid, butyrolactone, tensyuic acids, emodin, kojic acid, fumigaclavine, pseurotin, oleic acid, and $n$-hexadecanoic acid, in addition to lovastatin [68-71].

In the present study, a yeast growth inhibition bioassay was performed to verify the antifungal potential of intra- and extracellular fractions of $A$. terreus KPR12 against Candida tropicalis ASY2. The growth of C. tropicalis ASY2 was inhibited in both control and fungal

Table 3 Lovastatin production by A. terreus KPR12 compared with other reports

\begin{tabular}{|c|c|c|c|c|}
\hline A. terreus strain & Carbon source & Specific supplements/factors & Yield $\left(\mathrm{mg} \mathrm{L}^{-1}\right)$ & References \\
\hline ATCC 20542 & Lactose, glycerol & - & 161.8 & Bizukojc and Pecyna [80] \\
\hline JPM3 & Glucose & - & 138.4 & Jaivel and Marimuthu [56] \\
\hline Z15-7 & Glycerol & Mutant & 916.7 & Li et al. [61] \\
\hline LA414 & Soluble starch & Polyketide antibiotic & 952.7 & Jia et al. [62] \\
\hline NRRL 255 & $\begin{array}{l}\text { Glucose malt extract milk } \\
\text { powder }\end{array}$ & Reactor & 920 & Gupta et al. [81] \\
\hline GD13 & Lactose & Cyclic mutagenesis & 1242 & Kaur et al. [60] \\
\hline LA414 & Soluble starch & - & 523.9 & Jia et al. [57] \\
\hline MUCL 38669 & Lactose, glucose & Linoleic acid supplements & 212.5 & Sorrentino et al. [31] \\
\hline KPR12 & Starch-based SWW & - & 450.79 (kinetic study) & Present study \\
\hline \multicolumn{5}{|l|}{ Monascus strain } \\
\hline MTCC 369 & Glucose & - & 737 & Ahmad et al. [82] \\
\hline MTCC 369 & Glucose & - & 351 & Sayyad et al. [83] \\
\hline
\end{tabular}




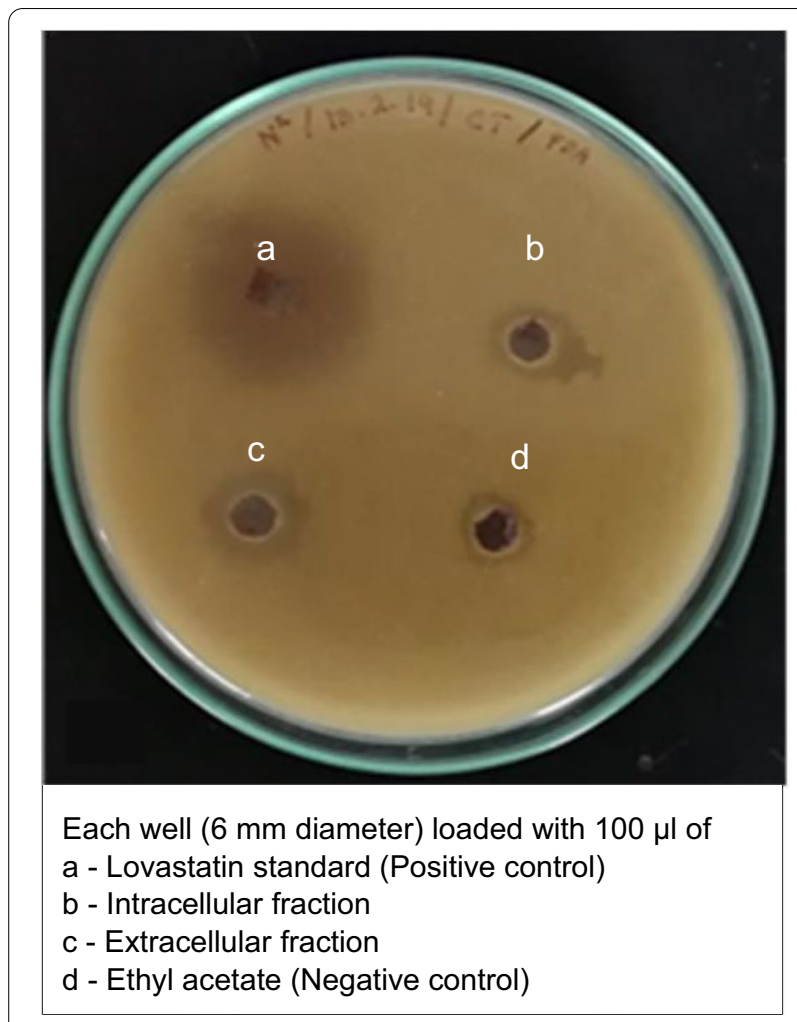

Fig. 7 Lovastatin extract of A. terreus KPR12 inhibiting the growth of yeast observed by the zone of inhibition around a colony

extracts, and clearing zones were observed (Fig. 7). The diameters of inhibition zones for both intra- and extracellular fractions in SWW were 12 and $14 \mathrm{~mm}$, respectively. The clear zone may be due to the combined effects of lovastatin and unidentified antimicrobial compounds present in the fungal extracts.

\section{Simultaneous decontamination of SWW}

In addition to lovastatin production, SWW can be treated and reused in the same industry for tuber washing or irrigation, or recreation purposes. The comparative evaluation of raw and spent SWW with national standards is presented in Table 4 . We detected a slight increase in $\mathrm{pH}$ from 6.5 to 7.1 of the treated SWW, suggesting that alkalinization may be due to the secretion of ammonia and its related compounds by the fungus during its growth in SWW [72] (Fig. 8). The very high EC $\left(6.2 \mathrm{dS} \mathrm{m}^{-1}\right)$ of raw SWW was reduced $\left(4.1 \mathrm{dS} \mathrm{m}^{-1}\right)$ after the fermentation due to the soluble salts metabolized by the growth of fungi. The salinity, TS, and TDS contents were also reduced in SWW (Table 4). The high organic matter content in SWW (COD and BOD) could be effectively fermented by oleaginous fungi by oxygen consumption, and the level reduced to 30.27 and $1.03 \mathrm{~g} \mathrm{~L}^{-1}$, respectively. Our earlier report by Candida tropicalis ASY2 also supported the present investigation [28]. Almost all nitrogen content in the SWW was used as a nitrogen source for fungal growth. A small amount of phosphate $\left(72.1 \mathrm{mg} \mathrm{L}^{-1}\right)$ was available in the treated SWW. The bound cyanide in the tapioca roots was hydrolyzed by linamerase during the starch extraction process and left free cyanide in the waste stream. The microbe can grow and use cyanide-containing substrates through anaerobic metabolism, respiratory chain metabolism, and their ability to detoxify cyanide by splitting the $\mathrm{CN}$ radical into carbon and nitrogen $[73,74]$. In the present study, the cyanide content was

Table 4 Parametric comparison of raw and spent SWW with national standards

\begin{tabular}{|c|c|c|c|c|}
\hline Properties & $\begin{array}{l}\text { Raw SWW parameters } \\
\text { estimated in our study }\end{array}$ & $\begin{array}{l}\text { Treated SWW parameters } \\
\text { estimated in our study }\end{array}$ & $\begin{array}{l}\text { Different parameters of } \\
\text { SWW reported in other } \\
\text { studies }^{\mathrm{a}}\end{array}$ & $\begin{array}{l}\text { National effluent standards } \\
\text { for sago and starch industry }\end{array}$ \\
\hline $\mathrm{pH}$ & $4.67 \pm 0.03$ & $8.1 \pm 0.02$ & $4.5-5.5$ & $6.5-8.5$ \\
\hline $\mathrm{EC}\left(\mathrm{dS} \mathrm{m}^{-1}\right)$ & $6.3 \pm 0.04$ & $4.11 \pm 0.0$ & $1.7-3.3$ & - \\
\hline Salinity $\left(\mathrm{g} \mathrm{L}^{-1}\right)$ & $4.86 \pm 0.09$ & $2.15 \pm 0.03$ & - & - \\
\hline Total solids $\left(\mathrm{g} \mathrm{L}^{-1}\right)$ & $4.57 \pm 0.01$ & $1.86 \pm 0.01$ & $0.8-12.45$ & 0.1 \\
\hline Total dissolved solids $\left(\mathrm{g} \mathrm{L}^{-1}\right)$ & $4.16 \pm 0.02$ & $1.32 \pm 0.04$ & $1.5-3.7$ & - \\
\hline $\operatorname{Starch}\left(g L^{-1}\right)$ & $10.00 \pm 0.07$ & $0.002 \pm 0.0$ & $4-7$ & - \\
\hline $\mathrm{BOD}\left(\mathrm{g} \mathrm{L}^{-1}\right)$ & $5.04 \pm 0.08$ & $1.03 \pm 0.12$ & $6.2-23.1$ & 0.03 \\
\hline $\operatorname{COD}\left(\mathrm{g} \mathrm{L}^{-1}\right)$ & $70.22 \pm 1.1$ & $30.27 \pm 1.2$ & $11.08-19.08$ & 0.25 \\
\hline $\mathrm{NO}_{3}\left(\mathrm{mg} \mathrm{L}^{-1}\right)$ & $3.10 \pm 0.02$ & ND & - & 10 \\
\hline $\mathrm{NH}_{4}\left(\mathrm{mg} \mathrm{L}^{-1}\right)$ & $5.48 \pm 0.05$ & ND & - & 50 \\
\hline $\mathrm{PO}_{4}\left(\mathrm{mg} \mathrm{L}^{-1}\right)$ & $611.67 \pm 0.01$ & $72.1 \pm 0.04$ & - & 5 \\
\hline Cyanide $\left(\mathrm{mg} \mathrm{L}^{-1}\right)$ & $4.46 \pm 0.02$ & $1.54 \pm 0.32$ & $3.5-5.3$ & 0.2 \\
\hline
\end{tabular}

\footnotetext{
${ }^{a}$ Adopted from Sujatha and Kumar [74]; Bhaskar and Prasada Rao [84], and Priya et al. [85]
} 


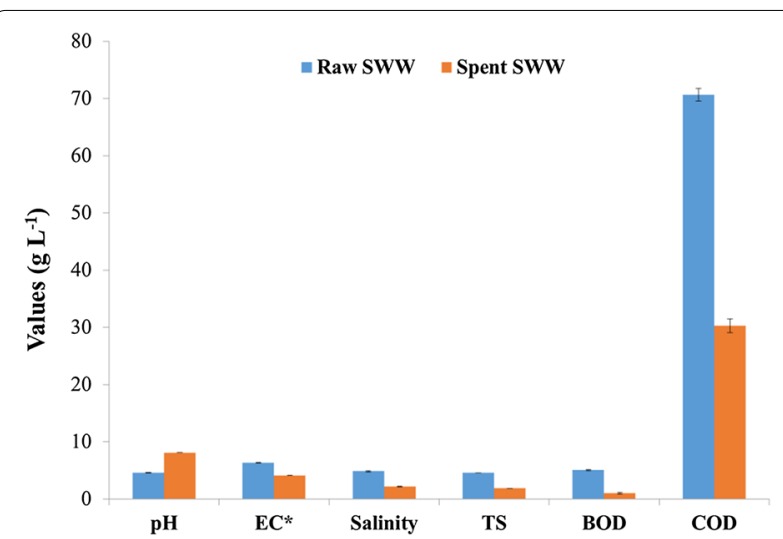

Fig. 8 Decontamination of SWW during lovastatin production by A. terreus KPR12. EC, electrical conductivity; TS, total solids; BOD, biochemical/biological oxygen demand; $C O D$, chemical oxygen demand. * $\mathrm{dS} \mathrm{m} \mathrm{m}^{-1}$; units for all the other parameters are $\mathrm{g} \mathrm{L}^{-1}$

reduced to $1.54 \mathrm{mg} \mathrm{L}^{-1}$. The results were supported by preliminary works of Kandasamy [75], who isolated bacterial isolates that could tolerate up to $5 \mathrm{mM}$ cyanide. However, further secondary treatment such as anaerobic digestion $[76,77]$ and extended aeration [78, 79] will further reduce the pollutant content of SWW and would pave the way for the reuse of spent SWW for various applications.

\section{Conclusion}

A. terreus KPR12 produced an optimal titer of $450.79 \mathrm{mg} \mathrm{L}^{-1}$ lovastatin in SWW without additional nutritional input or strain improvement techniques. These findings pave the way for the cost-effective and efficient production of lovastatin by microbial fermentation, in which soluble starch in SWW is effectively converted into valuable by-products. Such an integrated application of A. terreus KPR12, along with the use of industrial waste streams, can provide new leads for the development of statin as well as effective waste management.

\begin{abstract}
Abbreviations
SWW: Sago processing wastewater; SM: Synthetic medium; SmF: Submerged fermentation; SSF: Solid-state fermentation; EC: Electrical conductivity; BOD: Biochemical/biological oxygen demand; COD: Chemical oxygen demand; UV: Ultraviolet; FTIR: Fourier transform-infrared; HPLC: High-performance liquid chromatography; ANOVA: Analysis of variance; $Y_{\text {Lov } x:}$ : Lovastatin to biomass yield coefficient; $Y_{\text {Lov/s: }}$ Lovastatin to substrate yield coefficient; $Y_{x / s}$ : Biomass to starch yield coefficient; $X_{\text {FINAL }}$ : Biomass weight; $Q_{\text {max }}$ : Lovastatin specific formation rate.
\end{abstract}

\section{Acknowledgements}

We thank the Department of Biotechnology (No. BT/PR8280/

PBD/26/382/2013), New Delhi, GOI, and Metabolomic and Proteomic Analytical Facility (MPAF) at Tamil Nadu Agricultural University, Coimbatore, India for sharing their equipment for various analyses carried out in the present study.

\section{Authors' contributions}

SU: Conceptualized the idea and received research grants from DBT. SU, NS, and KT: Designed the experiments. NS and KT: Conducted the experiments. SU and NS: Analyzed the data and discussed the results. NS and KT: Wrote the manuscript. All authors helped in reviewing the manuscript. All authors read and approved the final manuscript.

\section{Funding}

We would like to thank DBT-Gol for the financial support for the project entitled "Biodiesel production: Sago processing industrial wastewater as feedstock for the microbial production of oil and derived co-products" granted to SU for financial support (File no. BT/PR8280/PBD/26/382/2013 dated 20.03.2015).

\section{Availability of data and materials}

All data generated or analyzed during this study are included in this published article.

\section{Declarations}

\section{Ethics approval and consent to participate}

Not applicable.

\section{Consent for publication}

All authors have participated in the research study and manuscript preparation.

\section{Competing interests}

The authors hereby declare that they have no conflict of interest.

\section{Author details}

${ }^{1}$ Biocatalysts Laboratory, Department of Agricultural Microbiology, Tamil Nadu Agricultural University, Coimbatore, Tamil Nadu 641 003, India. ${ }^{2}$ Department of Renewable Energy Engineering, Agricultural Engineering College and Research Institute, Tamil Nadu Agricultural University, Coimbatore, Tamil Nadu 641 003, India. ${ }^{3}$ Present Address: Department of Agriculture Engineering, Mahendra Engineering College, Namakkal, Tamil Nadu 637 503, India.

Received: 21 September 2021 Accepted: 25 January 2022

Published online: 14 February 2022

\section{References}

1. Jeong S-M, Choi S, Kim K, Kim S-M, Lee G, Son JS, Yun J-M, Park SM. Association of change in total cholesterol level with mortality: a populationbased study. PLOS ONE. 2018;13:1-11.

2. Collins R, Reith C, Emberson J, Armitage J, Baigent C, Blackwell L, Blumenthal R, Danesh J, Smith GD, DeMets D. Interpretation of the evidence for the efficacy and safety of statin therapy. Lancet. 2016;388:2532-61.

3. Lai L-ST, Tsai T-H, Cheng T-Y. The influence of culturing environments on lovastatin production by Aspergillus terreus in submerged cultures. Enzyme Microb Technol. 2005;36:737-48.

4. Endo A. The origin of the statins. In: International congress series. Elsevier; 2004: 3-8.

5. Barrios-González J, Miranda RU. Biotechnological production and applications of statins. Appl Microbiol Biotechnol. 2010;85:869-83.

6. Seenivasan A, Venkatesan S, Tapobrata P. Cellular localization and production of lovastatin from Monascus purpureus. Indian J Pharm Sci. 2018;80:85-98.

7. Zhao Q, Li M, Chen M, Zhou L, Zhao L, Hu R, Yan R, Dai K. Lovastatin induces platelet apoptosis. Environ Tox Pharm. 2016;42:69-75.

8. Bizukojc M, Ledakowicz S. Physiological, morphological and kinetic aspects of lovastatin biosynthesis by Aspergillus terreus. Biotechnol J. 2009:4:647-64.

9. Dikshit R, Tallapragada P. Bio-synthesis and screening of nutrients for lovastatin by Monascus sp. under solid-state fermentation. J Food Sci Technol. 2015;52:6679-86.

10. Hassan SW, Farag AM, Beltagy EA. Purification, characterization and anticancer activity of $\mathrm{L}$-asparaginase produced by marine Aspergillus terreus. J Pure Appl Microbiol. 2018;12:1845-54. 
11. Seydametova E, Salihon J, Zainol N, Convey P. Production of Lovastatin by Penicillium spp. soil microfungi. Int J Chem Eng Appl. 2012;3:337.

12. Upendra RS, Pratima K, Amiri ZR, Shwetha L, Ausim M. Screening and molecular characterization of natural fungal isolates producing lovastatin. J Microb Biochem Technol. 2013;5:25-30.

13. Manzoni M, Rollini M. Biosynthesis and biotechnological production of statins by filamentous fungi and application of these cholesterol-lowering drugs. Appl Microbiol Biotechnol. 2002;58:555-64.

14. Kamath PV, Dwarakanath BS, Chaudhary A, Janakiraman S. Optimization of culture conditions for maximal lovastatin production by Aspergillus terreus (KM017963) under solid state fermentation. HAYATI J Biosci. 2015:22:174-80.

15. Mulder KC, Mulinari F, Franco OL, Soares MS, Magalhães BS, Parachin NS. Lovastatin production: from molecular basis to industrial process optimization. Biotechnol Adv. 2015;33:648-65.

16. Praveen V, Savitha J. Solid state fermentation: an effective method for lovastatin production by fungi over submerged fermentation. J Biotech Pharma Res. 2012:3:15e21.

17. Saravanane R, Murthy D, Krishnaiah K. Anaerobic fluidized bed degradation and the development of a kinetic model for a particulate organic matter enriched wastewater sludge. Water Air Soil Pollut. 2001;127:15-30

18. Savitha S, Sadhasivam S, Swaminathan K, Lin FH. A prototype of proposed treatment plant for sago factory effluent. J Clean Prod. 2009;17:1363-72.

19. Pandian PS, Meenambal T. Development and performance analysis of two-stage biological process adopted in sago industries for treatment of high organic effluent. Int J Res Advent Technol. 2017;5:7-11.

20. de Carvalho JC, Borghetti IA, Cartas LC, Woiciechowski AL, Soccol VT, Soccol CR. Biorefinery integration of microalgae production into cassava processing industry: potential and perspectives. Bioresour Technol. 2018;247:1165-72.

21. Thangavelu K, Sundararaju P, Srinivasan N, Uthandi S. Bioconversion of sago processing wastewater into biodiesel: optimization of lipid production by an oleaginous yeast, Candida tropicalis ASY2 and its transesterification process using response surface methodology. Microb Cell Fact. 2021:20:1-18

22. Elaiyaraju P, Partha N. Biogas production from Sago (Tapioca) wastewater using anaerobic batch reactor. Energy Environ. 2012;23:631-45.

23. Sangeetha V, Sivakumar V. Biogas production from synthetic sago wastewater by anaerobic digestion: optimization and treatment. Chem Ind Chem Eng Q. 2016;22:33-9.

24. Amorim NCS, Alves I, Martins JS, Amorim ELC. Biohydrogen production from cassava wastewater in an anaerobic fluidized bed reactor. Braz J Chem Eng. 2014;31:603-12.

25. Khongkliang P, Kongjan P, Utarapichat B, Reungsang A, Sompong O. Continuous hydrogen production from cassava starch processing wastewater by two-stage thermophilic dark fermentation and microbial electrolysis. Int J Hydrog Energy. 2017;42:27584-92.

26. Naganandhini SK, Thangavelu K, Sekar A, Uthandi S. Aspergillus caespitosus ASEF14, oleaginous fungi as a potential candidate for biodiesel production using starch processing wastewater. Microbial Cell Fact. 2021;20(1):1-23.

27. Sivakumar U, Kiruthika T, Naganandhini S. Decontamination and simultaneous lipid production from sago processing wastewater by oleaginous yeast strain and uses thereof, 201941020275. Indian patent 2019.

28. Thangavelu K, Sundararaju P, Srinivasan N, Muniraj I, Uthandi S. Simultaneous lipid production for biodiesel feedstock and decontamination of sago processing wastewater using Candida tropicalis ASY2. Biotechnol Biofuels. 2020;13:1-14.

29. Thangavelu K, Sundararaju P, Srinivasan N, Uthandi S. Characterization of biomass produced by Candida tropicalis ASY2 grown using sago processing wastewater for bioenergy applications and its fuel properties. Biomass Convers Biorefin. 2021;1-14.

30. Ashika S, Kiruthika T, Ashokkumar K, Suraj H, Uthandi S. Oleaginous yeast from Sago waste water: screening and characterization of Candida trophicalis for biolipid production. Madras Agric J. 2017;104:288.

31. Sorrentino F, Roy I, KeshavarzT. Impact of linoleic acid supplementation on lovastatin production in Aspergillus terreus cultures. Appl Microbiol Biotechnol. 2010;88:65-73.

32. Manzoni M, Bergomi S, Rollini M, Cavazzoni V. Production of statins by filamentous fungi. Biotechnol Lett. 1999;21:253-7.
33. Lingappa K, Babu V, Siddalingeshwar KG, Pramod T. Isolation, screening and rapid confirmation of lovastatin producing strains of Aspergillus terreus. Indian J Microbiol. 2004;44 (2):133-135.

34. Samiee SM, Moazami N, Haghighi S, Aziz Mohseni F, Mirdamadi S, Bakhtiari MR. Screening of lovastatin production by filamentous fungi. Iran Biomed J. 2003;7:29-33.

35. Dubois M, Gilles KA, Hamilton JK, Rebers P, Smith F. Colorimetric method for determination of sugars and related substances. Anal Chem. 1956:28:350-6.

36. Babu RH, Rupa A, Radha S, Prasad N, Narasimha G. Screening of lovastatin producing fungi by yeast growth inhibition assay method. J Pharm Res. 2011:4:2967-8.

37. Friedrich J, Žužek M, Benčina M, Cimerman A, Štrancar A, Radež IJ. Highperformance liquid chromatographic analysis of mevinolin as mevinolinic acid in fermentation broths. J Chromatogr A. 1995;704:363-7.

38. APHA. Standard methods for the examination of water and wastewater. Federation, Water Environmental APH Association, American Public Health Association, Washington, DC. 2005.

39. Fisher F, Brown J. Colorimetric determination of cyanide in stack gas and waste water. Anal Chem. 1952:24:1440-4.

40. Addinsoft S. XLSTAT software, version 9.0. Paris: Addinsoft; 2010.

41. Yang D-J, Hwang LS. Study on the conversion of three natural statins from lactone forms to their corresponding hydroxy acid forms and their determination in Pu-Erh tea. J Chromatogr A. 2006;1119:277-84.

42. Endo A. Monacolin K, a new hypocholesterolemic agent produced by a Monascus species. J Antibiot. 1979;32:852-4.

43. Mohaček-Grošev V, Božac R, Puppels GJ. Vibrational spectroscopic characterization of wild growing mushrooms and toadstools. Spectrochim Acta A Mol Biomol Spectrosc. 2001;57:2815-29.

44. Raja Rajeswari K, Abbulu K, Sudhakar M, Vishwanadhami M, Tejaswini M. Studies on dissolution enhancement of lovastatin using soluplus by solid dispersion technique. Int J Pharm Pharm Sci. 2012;4:124-8.

45. Miao L, Kwong TF, Qian P-Y. Effect of culture conditions on mycelial growth, antibacterial activity, and metabolite profiles of the marinederived fungus Arthrinium c.f. saccharicola. Appl Microbiol Biotechnol. 2006;72:1063-73.

46. Koroglu EO, Yoruklu HC, Demir A, Ozkaya B. Scale-up and commercialization issues of the MFCs: challenges and implications. In: Microbial electrochemical technology. Elsevier; 2019. p. 565-83.

47. Bengtsson B-E, Triet T. Tapioca-starch wastewater toxicity characterized by Microtox and duckweed tests. Ambio. 1994;23:473-7.

48. Zuhra K, Szabo C. The two faces of cyanide: an environmental toxin and a potential novel mammalian gasotransmitter. FEBS J. 2021;1-35.

49. Rodriguez Porcel E, Casas Lopez J, Sanchez Perez J, Chisti Y. Enhanced production of lovastatin in a bubble column by Aspergillus terreus using a two-stage feeding strategy. J ChemTechnol Biotechnol Int Res Proc Environ Clean Technol. 2007:82:58-64.

50. López JC, Pérez JS, Sevilla JF, Fernández FA, Grima EM, Chisti Y. Production of lovastatin by Aspergillus terreus: effects of the $\mathrm{C}: \mathrm{N}$ ratio and the principal nutrients on growth and metabolite production. Enzyme Microb Technol. 2003:33:270-7.

51. Hendrickson L, Davis CR, Roach C, Aldrich T, McAda PC, Reeves CD. Lovastatin biosynthesis in Aspergillus terreus: characterization of blocked mutants, enzyme activities and a multifunctional polyketide synthase gene. Chem Biol. 1999;6:429-39.

52. Robinson PK. Enzymes: principles and biotechnological applications. Essays Biochem. 2015;59:1.

53. Hajjaj H, Niederberger P, Duboc P. Lovastatin biosynthesis by Aspergillus terreus in a chemically defined medium. Appl Environ Microbiol. 2001;67:2596-602.

54. Bizukojc M, Ledakowicz S. A macrokinetic modelling of the biosynthesis of lovastatin by Aspergillus terreus. J Biotechnol. 2007;130:422-35.

55. Pawlak M, Bizukojć M. Kinetic modelling of lovastatin biosynthesis by Aspergillus terreus cultivated on lactose and glycerol as carbon sources. Chem Process Eng. 2012;33:651-65.

56. Jaivel N, Marimuthu P. Isolation and screening of lovastatin producing microorganisms. Int J Eng Sci Technol. 2010;2:2607-11.

57. Jia Z, Zhang $X$, Zhao $Y$, Cao $X$. Effects of divalent metal cations on lovastatin biosynthesis from Aspergillus terreus in chemically defined medium. World J Microbiol Biotechnol. 2009;25:1235-41. 
58. Pecyna M, Bizukojc M. Lovastatin biosynthesis by Aspergillus terreus with the simultaneous use of lactose and glycerol in a discontinuous fedbatch culture. Biotechnol J. 2011;151:77-86.

59. Sridevi B, Charya MAS. Isolation, identification and screening of potential cellulase-free xylanase producing fungi. Afr J Biotechnol. 2011;10:4624-30.

60. Kaur H, Kaur A, Saini H, Chadha B. Screening and selection of lovastatin hyper-producing mutants of Aspergillus terreus using cyclic mutagenesis. Acta Microbiol Immunol Hung. 2009;56:169-80.

61. Li S-W, Li M, Song H-P, Feng J-L, Tai X-S. Induction of a high-yield lovastatin mutant of Aspergillus terreus by 12 C $6+$ heavy-ion beam irradiation and the influence of culture conditions on lovastatin production under submerged fermentation. Appl Biochem Biotechnol. 2011;165:913-25.

62. Jia Z, Zhang $X$, Zhao $Y$, Cao $X$. Enhancement of lovastatin production by supplementing polyketide antibiotics to the submerged culture of Aspergillus terreus. Appl Biochem Biotechnol. 2010;160:2014-25.

63. Al-Fakih AA, Almaqtri WQA. Overview on antibacterial metabolites from terrestrial Aspergillus spp. Mycology. 2019;10:191-209.

64. Xu W, Li G, Huang X, Luo Z. Fungal diversity study in the deep sea sediments of three oceans by culture-dependent approach. J Appl Oceanogr. 2015;34:103-10

65. Brilhante RSN, Caetano EP, Oliveira JSd, Castelo-Branco DdSCM, Souza ERY, Alencar LPd, Cordeiro RdA, Bandeira TdJPG, Sidrim JJC, Rocha MFG. Simvastatin inhibits planktonic cells and biofilms of Candida and Cryptococcus species. Braz J Infect Dis. 2015;19:459-65.

66. Lorenz R, Parks L. Effects of lovastatin (mevinolin) on sterol levels and on activity of azoles in Saccharomyces cerevisiae. Antimicrob Agents Chemother. 1990;34:1660-5.

67. Macreadie IG, Johnson G, Schlosser T, Macreadie PI. Growth inhibition of Candida species and Aspergillus fumigatus by statins. FEMS Microbiol Lett. 2006:262:9-13.

68. Cazar M, Schmeda-Hirschmann G, Astudillo L. Biotechnology: antimicrobial butyrolactone I derivatives from the Ecuadorian soil fungus Aspergillus terreus Thorn. var terreus. World J Microbiol Biotechnol. 2005;21:1067-75

69. Chang M, Wang J, Tian F, Zhang Q, Ye B. Antibacterial activity of secondary metabolites from Aspergillus awamori F12 isolated from rhizospheric soil of Rhizophora stylosa Griff. Wei Sheng Wu Xue Bao. 2010;50:1385-91.

70. Pinheiro EAA, Carvalho JM, dos Santos DCP, Feitosa AdO, Marinho PSB, Guilhon GMSP, de Souza ADL, da Silva FMA, Marinho AMdR. Antibacterial activity of alkaloids produced by endophytic fungus Aspergillus sp. EJC08 isolated from medical plant Bauhinia guianensis. Nat Prod Res. 2013;27:1633-8.

71. Yahaya S, Idris B, Yusuf I, Rabiu MK. Screening and identification of antibacterial agents produced by Aspergillus species from the soil of Bayero University Kano. Bayero J Pure Appl Sci. 2017;10:498-502.

72. Vylkova S. Environmental pH modulation by pathogenic fungi as a strategy to conquer the host. PLoS Pathog. 2017;13:e1006149.

73. Jensen $\mathrm{H}$, Abdel-Ghaffar A. Cyanuric acid as nitrogen source for microorganisms. Arch Mikrobiol. 1969;67:1-5.

74. Sujatha K, Kumar K. Variations on physicochemical characteristics of waste water from Sago industries of Salem, Tamil nadu. J Ecotoxicol Environ Monit. 2011;23:185-90.

75. Kandasamy S, Dananjeyan B, Krishnamurthy K, Benckiser G. Aerobic cyanide degradation by bacterial isolates from cassava factory wastewater. Braz J Microbiol. 2015;46:659-66.

76. Colin X, Farinet JL, Rojas O, Alazard D. Anaerobic treatment of cassava starch extraction wastewater using a horizontal flow filter with bamboo as support. Bioresour Technol. 2007;98:1602-7.

77. Priya M, Meenambal T, Balasubramanian N, Perumal B. Comparative study of treatment of sago wastewater using HUASB reactor in the presence and absence of effective microorganisms. Procedia Earth Planet Sci. 2015;11:483-90

78. Kandasamy S, Dananjeyan B, Krishnamurthy K. Potential of continuous and intermittent aeration for sago wastewater treatment. Ecoscan. 2013:7:129-32.

79. Wahi AR, Hamdan M, King W, Kopli B. The potential of extended aeration system for sago effluent treatment. Am J Appl Sci. 2010;7:616-9.

80. Bizukojc M, Pecyna M. Lovastatin and (+)-geodin formation by Aspergillus terreus ATCC 20542 in a batch culture with the simultaneous use of lactose and glycerol as carbon sources. Eng Life Sci. 2011;11:272-82.
81. Gupta K, Mishra P, Srivastava P. A correlative evaluation of morphology and rheology of Aspergillus terreus during lovastatin fermentation. Biotechnol Bioprocess Eng. 2007;12:140-6.

82. Ahmad A, Panda BP, Khan S, Ali M, Javed S. Downstreaming and purification of lovastatin from Monascus purpureus culture. Thai J Pharm Sci. 2009;33:39-46.

83. Sayyad SA, Panda BP, Javed S, Ali M. Optimization of nutrient parameters for lovastatin production by Monascus purpureus MTCC 369 under submerged fermentation using response surface methodology. Appl Microbiol Biotechnol. 2007;73:1054-8.

84. Bhaskar C, Rao P. Potential of sago effluent for agricultural use. Int J Environ Ecol Fam Urban Stud. 2014;4:31-6.

85. Priya M, Meenambal T, Balasubramanian N, Perumal B. Comparative study of treatment of sago wastewater using HUASB reactor in the presence and absence of effective microorganisms. J Procedia Earth Planet Sci. 2015;11:483-90.

\section{Publisher's Note}

Springer Nature remains neutral with regard to jurisdictional claims in published maps and institutional affiliations.
Ready to submit your research? Choose BMC and benefit from:

- fast, convenient online submission

- thorough peer review by experienced researchers in your field

- rapid publication on acceptance

- support for research data, including large and complex data types

- gold Open Access which fosters wider collaboration and increased citations

- maximum visibility for your research: over $100 \mathrm{M}$ website views per year

At BMC, research is always in progress.

Learn more biomedcentral.com/submissions 